\title{
Accuracy of Solar Eclipse Calculation Algorithm Based on Jet Propulsion Laboratory Data Nasa
}

\author{
M. Basthoni \\ Program Doktor Studi Islam Universitas Islam Negeri Walisongo Semarang- \\ Indonesia \\ e-mail:m.basthoni@gmail.com
}

\begin{abstract}
DE200 and DE405 are Development Ephemeris (DE) series released by the National Aeronautics and Space Administration (NASA) in 1981 and 1997. NASA uses DE405 to predict solar eclipses in 2011-2020. While before 2011 and after 2020 NASA uses VSOP87/ELP200 theory-based DE200. Why NASA not only use more updated series DE405 and still use old release DE200? What is the difference of DE200 accuracy compared to DE405 to predict solar eclipse? This needs to be researched because the solar eclipse predicted by NASA is used as a reference by the researchers. To answer this question, this paper proposes a solar eclipse computation algorithm based on DE200 and DE405 data and the results will be compared with the results of observations of the March 9,2016, solar eclipse that have been carried out Langit Selatan to find out a more accurate DE series. The results of this study indicate that the DE200 series is more accurate than DE405 with an average difference of $0.5-0.6$ seconds with the results of observations.
\end{abstract}

Keywords: ephemeris accuracy, solar eclipse, JPL NASA

Seri DE200 dan DE405 merupakan seri Development Ephemeris yang telah dirilis oleh National Aeronautics and Space Administration (NASA) pada 1981 dan 1997. NASA menggunakan basis data DE405 untuk memprediksi gerhana Matahari tahun 2011 2020. Sementara sebelum tahun 2011 dan setelah 2020, NASA menggunakan teori VSOP87 dan ELP2000 yang berbasis pada DE200. Mengapa NASA tidak hanya menggunakan yang lebih update yaitu DE405? Sejauh mana akurasi DE200 dibandingkan dengan DE405 untuk memprediksi fenomena gerhana Matahari? Hal ini penting untuk diungkap karena selama ini prediksi gerhana Matahari yang dirilis oleh NASA tersebut sering dijadikan acuan oleh para peneliti. Untuk menjawab pertanyaan tersebut, tulisan ini mengusulkan algoritma komputasi gerhana matahari berbasis data DE200 dan DE405 dan hasilnya akan dibandingkan dengan hasil observasi gerhana Matahari 9 Maret 2016 yang telah dilakukan Langit Selatan untuk mengetahui seri DE yang lebih akurat Hasil kajian ini menunjukkan bahwa seri DE200 lebih akurat dibanding DE405 dengan selisih rata-rata 0,5 - 0,6 detik dengan hasil observasi.

Kata Kunci: akurasi ephemeris, gerhana Matahari,JPL NASA 


\section{Introduction}

High precision Sun and Moon ephemeris ${ }^{1}$ data is needed for calculations in astronomy, for example determining the exact solar eclipse prayer time ${ }^{2}$ in accordance with the guidance of the Shari'a and determining the beginning of the Islamic month. Because the time of its implementation is closely related to the regularity of the positions and movements of the two celestial bodies 3 . Associated with the need for a high degree of accuracy, Jean Meeus said that accuracy is needed in the calculation of conjunctions because of the thin disk of the two celestial objects observed when in conjunction position. Conjunction events for example occur in the phenomenon of the solar eclipse and every beginning of the Islamic month ${ }^{4}$.

National Aeronautics and Space Administration (NASA) through one of its divisions, Jet Propulsion Laboratory (JPL) ${ }^{5}$, has released several Development Ephemeris (DE) ${ }^{6}$ series to support various astronomical expedition missions.

\footnotetext{
${ }^{1}$ Ephemeris which in Arabic is called zij is a table that contains astronomical data on celestial bodies. Susiknan Azhari, Ensiklopedi Hisab Rukyat (Yogyakarta: Pustaka Pelajar, 2012), 61-62.

${ }^{2}$ In determining the time of the eclipse prayer, the Prophet gave a signal by saying "When you see an eclipse then recite (prayer) until both of them recover". Muslim bin Al-Hajajāj, Șahịh Muslim (Libanon: Dār al-Fikr, 1992), 397-398.

The scholars agree that one of the legal requirements for prayer is knowing when to enter the prayer time. Abi Yahya Zakariyaasserted that whoever performs the prayer without knowing the time, the prayer is invalid even if he performs it on time. Abī Yahyā Zakariya, Fath Al-Wahhāb, I (Semarang: Usaha Keluarga, n.d.), 48. More details Ibn Ali Nawawy added that the beginning of the solar eclipse prayer time began when there was a change in the shape of the Sun because it was covered by the Moon disc (first contact) while the solar eclipse prayer time ended when the Sun had recovered as before (the last contact) or the Sun had set even though it was still in a state eclipse. Muhammad bin 'Amr bin 'Alī Nawawy, Nihāyah Al-Zayn Fī Irshād Al-Mubtadi'īn (Libanon: Dār al-Fikr, n.d.), 110.

${ }^{3}$ Hendro Setyanto, Membaca Langit (Jakarta: al-Ghuraba, 2008), 45.

4 Jean Meeus, Astronomical Algorithms (Richmond:Willmann-Bell, Inc., 1991), 15.

5 NASA's Jet Propulsion Laboratory (JPL) is a division at Caltech (California Institute of Technology) Southern California, Boulevard, Pasadena, California, United States which is the center of research and exploration of the solar system, including covering the Earth and its atmosphere. See: NASA, Jet Propulsion Laboratory', n.d.

${ }^{6}$ In JPL there is a Solar System Dynamics (SSD) research group whose products and services provided are planetary, satellite, cometic and asteroidal ephemeris data. See: NASA, 'About JPL Solar System Dynamics', n.d.
} 
Among these was DE2007 which later became the basis for the emergence of the VSOP82 ${ }^{8}$ theory which in its development was further developed into VSOP879. DE200 is also the basis for the emergence of ELP200010 theory. In the next development JPL also released DE40511 which was then used as a database to release solar eclipse predictions for the period of $2011-2020^{12}$. While before $2011^{13}$ and after 202014, NASA used VSOP87 and ELP2000 theories based on DE200. Why does NASA keep using DE200 (implemented in VSOP87 / ELP2000) while a more updated series, DE405, has been released? How does DE200's accuracy compare with DE405 to predict the phenomenon of a solar eclipse?

This study is important because so far the predicted solar eclipse released by NASA is often used as a reference benchmark for the accuracy of the astronomical calculations of several studies and astronomical books. For example Rinto Anugraha in Mekanika Benda Langit compares the results of

\footnotetext{
7 The DE200 series was released in September 1981 to cover ephemeris data in the range of 9 Dec 1599 - 31 March 2169. The DE200 series was used by Astronomical Almanac from 1984 to 2003. See: NASA, 'JPL Planetary and Lunar Ephemerides: Export Information', n.d.

8 This theory was developed by Pierre Bretagnon in 1982 based on the results of the JPL DE200 fitting. See: P. Bretagnon, 'Theorie Du Mouvement de l'ensemble Des Planetes (VSOP82)', Astronomy and Astrophysics 114 (1982): 278.
}

9 This theory was developed by Pierre Bretagnon with Gerrad Francou in 1987 based on VSOP82 theory. See: P. Bretagnon and G. Francou, 'Planetary Theories in Rectangular and Spherical Variables: VSOP87 Solution', Astronomy and Astrophysics 202 (1988): 309.

10 This theory was developed by M. Chapront-Touze, J. Chapront in 1982 based on JPL DE200. See: M. Chapront-Touze and J. Chapront, 'ELP 2000-85: A Semi-Analytical Lunar Ephemeris Adequate for Historical Times', Astronomy and Astrophysics 190 (1988): 342.

11 The DE405 series was released in May 1997 to cover ephemeris data in a range December 9, 1599 - February 20, 2201. See: NASA, 'JPL Planetary and Lunar Ephemerides : Export Information'. Starting in 2003 DE405 is used by Astronomical Almanac. See: Fred Espenak, 'Solar Eclipse Predictions with JPL DE405', n.d.

12 See for example the prediction of a solar eclipse on May 20, 2012 by NASA at: NASA, "Annular Solar Eclipse of 2012 May 20," accessed December 6, 2019, https://eclipse.gsfc.nasa.gov/SEgoogle/ SEgoogle2001/SE2012May20Agoogle.html. and prediction of a solar eclipse of December 14, 2020 by NASA at: NASA, "Total Solar Eclipse of 2020 Dec 14," accessed December 6, 2019, https://eclipse.gsfc.nasa.gov/SEgoogle/SEgoogle2001/SE2020Dec14Tgoogle.html.

${ }^{13}$ See for example the prediction of a solar eclipse on July 11,2010 by NASA at: NASA, "Total Solar Eclipse of 2010 Jul 11," accessed December 6, 2019, https://eclipse.gsfcnasa.gov/SEgoogle/SEgoogle 2001/SE2010Jul11Tgoogle.html.

14 See for example the prediction of a solar eclipse on June 10, 2021 by NASA at: NASA, "Annular Solar Eclipse of 2021 Jun 10," accessed December 6, 2019, https://eclipse.gsfc.nasa.gov/SEgoogle/ SEgoogle2001/SE2021Jun10Agoogle.html. 
solar eclipse calculations with data released by NASA and concludes that the results of the calculation are less than 1 minute with the NASA data ${ }^{15}$. The same thing was done by Fiki Nu'afi Qurrota Aini when comparing the algorithm developed by Jean Meeus and W.M. Smart in calculating solar eclipses. Jean Meeus's algorithm is considered more accurate because the results are very close to the predicted solar eclipse released by NASA ${ }^{16}$. Likewise Muhammad Falih when testing the accuracy of the solar eclipse calculation algorithm developed by Ali Mustofa in his work al-Natïjah al-Mahșūnah. In his study, Falih stated that the algorithm in the book was quite accurate because the results were very close to NASA's calculation, which was a difference of 1 second - 1 minute 20 seconds ${ }^{17}$.

On the other hand, existing studies of NASA's solar eclipse calculation algorithm based on data have not been exhaustive and only describe the flow of the use of applications developed by NASA to predict solar eclipses. For example Siti Lailatul Mukaromah ${ }^{18}$ in her study only explained how to use the javascript application developed by NASA that can be accessed at https://eclipse.gsfc. nasa.gov/JSEX/JSEX-AS.html without explaining the algorithm used in the application because it is indeed in the application does not describe anything related to the calculation algorithm but only the flow of application usage. For this reason, this study exists to reveal in detail the algorithm used by NASA in computing ephemeris data which was further developed by the author for the purposes of NASA data-based solar eclipse computing.

Before comparing the accuracy of the two DE series, this paper will describe the algorithm of each DE series to produce the ephemeris data needed in the calculation of total solar eclipse or ring solar eclipse ie the time of partial solar eclipse (first contact), the beginning of total solar eclipse (second contact), middle of the eclipse, end of the total solar eclipse (third contact) and end of the

15 Rinto Anugraha, Mekanika Benda Langit(Yogyakarta: Lab. Material Physics and Instrumentation Department of Physics FMIPA UGM, 2012), 147.

16 Fiki Nu'afi Qurrota Aini, "Studi Komparatif Sistem Perhitungan Gerhana Matahari Elements of Solar Eclipses Jean Meeus dan Textbook on Spherical Astronomy W.M. Smart” (Program Studi Ilmu Falak Fakultas Syariah dan Hukum UIN Walisongo Semarang, 2019), 62-63.

17 Muhammad Falih, "Metode Hisab Gerhana Matahari MenurutAli Mustofa dalam Kitab Al-Natijah Al-Mahșūnah" (Program Studi Ilmu Falak Fakultas Syariah dan Hukum UIN Walisongo, 2019), 94.

18 Siti Lailatul Mukarromah, 'Perhitungan Gerhana Matahari Dengan Algoritma NASA', Ulul Albab: Jurnal Studi dan Penelitian Hukum Islam 2, no. 2 (July 2019): 99, https://doi.org/10.30659/ jua.v2i2.3642. 
eclipse (last contact). Then the results of the eclipse calculation are compared with reports of observations of the solar eclipse that have been carried out in the south which were also reported by Lembaga Penerbangan dan Antariksa Nasional (LAPAN) ${ }^{19}$. DE series is said to be the most accurate if the smallest difference in calculation compared with empirical data from the observations ${ }^{20}$.

\section{Algorithm of Ephemeris Data Calculation Based on JPL NASA}

This section will describe the algorithm for obtaining ephemeris data from data files of the American Standard Code for Information Interchange (ASCII) Development Ephemeris (DE) of certain series released by NASA JPL which generally takes 3 (three) steps: (1) obtain ASCII ephemeris data files; (2) convert the ASCII file to binary format; and (3) reading binary data files to obtain ephemeris data on celestial objects (in this case Sun and Moon ephemeris data). The ephemeris data will be processed with certain algorithms so the prediction of solar eclipses based on NASA's JPL ephemeris data can be obtained in this study. These three steps are described in more detail below.

\section{Obtain ASCII Ephemeris Data Files}

There are two ways to obtain NASA's JPL ASCII ephemeris data files. First by buying the Planetary and Lunar Ephemerides JPL CD-ROM provided by Willmann-Bell, Inc. through the internet at the address www.willbell.com/ software/jpl.htm. The CD-ROM contains files DE200, DE405 and DE406.

Second, by downloading directly on the FTP server (file transfer protocol) that has been provided by NASA's JPL at ftp://ssd.jpl.nasa.gov/pub/eph/ planets/ascii. On the server there are directories for each DE series. For example DE200 data files can be downloaded at ftp://ssd.jpl.nasa.gov/pub/eph/ planets/ascii/de200/, DE405 data files can be downloaded at ftp://ssd.jpl. nasa.gov/pub/eph/planets/ascii/de405/ and so on. Within each of these folders there are three groups of files, namely the header.xxx file, the tespo.xxx

\footnotetext{
${ }^{19}$ Lembaga Penerbangan dan Antariksa Nasional, "The Elipse Gerhana Matahari Total, Catatam Peristiwa 9 Maret 2016', n.d.

20 In the study of philosophy of science that the key to the scientific method is empirical and can be proven. This means that a statement is considered true if it is in accordance with experience or observation. Hamdani, Filsafat Ilmu (Bandung: Pustaka Setia, 2011), 163.
} 
file and the ASCII data file which are broken up into several files whose number and size varies between one DE data series and another.

\section{Convert ASCII Files to Binary Format}

The first step to process the ASCII ephemeris data file is to convert it to binary format. The ASC2EPH program written by Paul J. Heafner can be used to do this ${ }^{21}$.

Before doing the conversion, the ASC2EPH file written in C is compiled first so that it becomes an executable file. In this case the computer and compiler specifications used in this study are Acer TravelMate P243 Notebook with Core i3-3110M 2.4GHz, 6 Giga Byte RAM, 500 Giga Byte Hard Drive, Astro 3 (Juno) Distro Operating System based on Debian Linux and GNU C Compiler (gcc) as c compiler.

The functions used by the asc2eph.c file are provided by other files, namely astrolib.h and support. $h$ as well as the default gcc compiler library file. So to make it easier to compile the asc2eph.c file, compile commands are collected together in the makefile.unx ${ }^{22}$ file which can then be easily called by the make command in the linux operating system. The command syntax is:

$$
\text { make -f makefile.unx }
$$

Where the -f option is a command to read the file "makefile.unx" included in the command.

The command will produce an executable file named asc2eph that is ready to be used to convert ASCII files to binary files.

$$
\text { ./asc2eph -i:ascp2000.405 -o:de405_2000.bin }
$$

This command will convert the ASCII ascp2000.405 file as input into the de405_2000.bin binary file that is ready to read with other programs to generate DE405-based ephemeris data. The same steps can be done for other DE series. In this study the DE series to be used is the DE200 and DE405 series.

Furthermore, the general algorithm of the asc2eph program is that the program will read the ASCII input data file inputted by the user. If successful, the program will then look for the HEADER.xxx file in the same folder and in

\footnotetext{
21 The source code can also be seen at: Paul J. Heafner, Fundamental Ephemeris Computations for Use with JPL Data (Virginia: Willmann-Bell, Inc., 1999),190-203.

22 The contents of the file can be seen: Heafner, 310-312.
} 
accordance with the series of data entered by the user. For example the input data file is DE405 series (example: ascp2000.405) then the program will look for the HEADER. 405 file. If the HEADER.405 file is not found, the program stops. But if the file is found, then proceed to the next procedure which is reading the file HEADER.405.

The process of reading the HEADER.405 file by this program is to read sequentially starting from KSIZE up to all existing GROUP (starting from GROUP 1010 to GROUP 1070) and parsing all constants in each GROUP. After completion, the program will read the ASCII data file (example: ascp2000.405) which contains constants that are continuations of GROUP 1070 located in the HEADER.405 file.

Data that is successfully read by the program from the HEADER.405 file and the ascp2000.405 file is then entered in a binary file whose name matches what was entered by the user (in this case, de405_2000.bin). So, the binary file contains data from the HEADER.405 file at the top of the file and continues the data file taken from the ascp2000.405 file ${ }^{23}$.

\section{Reading Binary Data Files to Obtain Sun and Moon Ephemeris Data}

Ephemeris data obtained in the reading process of this binary data file are not all ephemeris data but only some data is needed in the process of comparing the accuracy of several DE series with the case of solar eclipse calculation which will be discussed in the next sub-chapter. The binary files read in this study are the DE200 and DE405 series.

Ephemeris data generated in this study is the ephemeris data of the Sun and Moon which includes ecliptic longitude, ecliptic latitude, apparent right ascension, apparent declination, true geocentric distance, semi diameter. For the Sun ephemeris data, true obliquity and equation of time data are also produced, while for the Moon data, horizontal parallax data is produced.

The reading of this data is carried out by the Sephem program (Small Ephemeris Program). This sephem program is a frontend in the ephemeris data reading process. This means that this file relies on procedures contained in other files as file dependencies. The files are astrocon.h, support.h, support.c, astrolib.h and astrolib.c.

${ }^{23}$ Summarized from the source code file asc2eph.c in: Heafner, 190-203. 
Each of these files handles some of the procedures contained in the file sephem which are described as follows. The astrocon.h file contains constants and basic commands for unit conversions. For example D2R which functions to change the unit of degrees to radians. The support. $h$ file contains prototypes of some basic text handling functions whose detailed instructions are inside the support.c file.

For example in supporth there is a prototype function to cut text from the left as follows:

$$
\text { void left(char str[], int n, char dest[]); }
$$

the detailed contents of the function are contained in the support.c file: void left(char str[], int $n$, char dest]]) \{if ( $\mathrm{n}>0)$ \{strncpy (dest, str, $n$; dest[n] = $\left.' \backslash 0^{\prime} ;\right\}$ else $\{$ strcpy(dest,""); $\left.\}\right\}$

The core of the algorithm for obtaining NASA JPL-based ephemeris data is in the astrolib. $h$ and astrolib.c files. Where the astrolib. $h$ file contains a prototype of a function whose detailed contents are written in the astrolib.c file which then by the sephem program these functions are called to obtain ephemeris data.

In detail the algorithm of the sephem program is described as follows. First when it is run, the program will request input binary files (e.g. de405_2000.bin) as a database to generate ephemeris data. Furthermore, the contents of the binary file are read by the ephopn ${ }^{24}$ function and the results are stored in memory as data for the next process, but if the input binary file is not found, the program will stop.

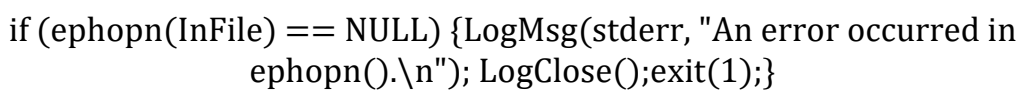

Then the program will ask for input date, month, year and time in UT. The input is then converted to time in JDE format by the Cal2JED function.

$$
\text { Cal2JED (month, day, year, utc, 4, utc, utc, 0, \&TDB); }
$$

After obtaining time in JED, the user is faced with two choices, namely the 'Ephemeris' menu to generate Sun and Moon ephemeris data. The second menu is the 'Solar Eclipse' menu to generate topocentric solar eclipse predictions. This second menu was developed in this research as a tool to test the accuracy of ephemeris data generated from this sephem program.

\footnotetext{
${ }^{24}$ Detailed contents of the ephopn function command and other functions that will be discussed in the next description can be seen in the astrolib.c file in: Heafner, 204-262.
} 
The 'Ephemeris' menu option will take the user to the next choice: the 'Sun' menu option to generate Sun ephemeris data and the 'Moon' option for the Moon ephemeris data.

The ephemeris data interval that is generated can be in hour intervals like the format in the book Ephemeris Hisab Rukyat Ministry of Religion of the Republic of Indonesia, the minute and second intervals according to the choices inputted by the user on the menu that appears after the user selects the Sun or Moon menu. This means that the ephemeris data released from this sephem program can be used by other calculation algorithms, for example solar and lunar eclipse calculations with the Ministry of Religion algorithm.

The following details the algorithm and source code of the ephemeris data generated by the sephem program.

Reduce(TDB, Targ, Place, StarData, p3); r = sqrt(p3[0] * p3[0] + p3[1] * p3[1]

$\left.+\mathrm{p} 3[2]^{*} \mathrm{p} 3[2]\right) ; \mathrm{RA}$ hours $=\operatorname{atan} 2(\mathrm{p} 3[1], \mathrm{p} 3[0]) * \mathrm{R} 2 \mathrm{H}$; if $(\mathrm{RA}$ hours $<0.0)$

$\{$ RA_hours $+=24.0$; $\}$ DEC_deg $=$ asin(p3[2] / r) *R2D;

The source code calls the 'reduce' function which functions to reduce the ephemeris data source so that it becomes apparent and topocentric ephemeris. The parameters needed by the 'reduce' function are the time in JED, the target for the object of the celestial object that is reduced and $p 3$ for the array of position vectors of a particular object.

The output from the 'reduce' function is then used for the process of finding the value of $r$ (distance of heavenly objects from the Earth), 'right ascension' value and 'declination' value. The value of $r$ is formulated with:

$$
r=\sqrt{p 3[0] * p 3[0]+p 3[1] * p 3[1]+p 3[2] * p 3[2]}
$$

Where the indexes 0,1 and 2 , respectively, are the vector position $x, y$ and $z$ of the object to be reduced.

'Right ascension' is the tan value from the ratio of vectors $y$ and $x$ in radians which is then converted to the hour format with the R2H (radians to hours) function. While 'declination' is the sin value from the comparison of $z$ and $r$ vectors in units of radians which is then converted in the degree format with the function R2D (radians to Degree).

After the $R A, D e c$ and $r$ values are obtained, these values are used as parameters for the transformation to ecliptic coordinates with the following source code.

$$
\text { r1[0] = RA_hours * H2R; }
$$


M Basthomi

$$
\begin{aligned}
& \mathrm{r} 1[1]=\mathrm{DEC}_{-} \mathrm{deg} * \mathrm{D} 2 \mathrm{R} \text {; } \\
& \mathrm{r} 1[2]=1.0 \text {; } \\
& \mathrm{r} 1[3]=0.0 \text {; } \\
& \mathrm{r} 1[4]=0.0 \\
& \mathrm{r} 1[5]=0.0 \text {; } \\
& \text { /* Change to rectangular variables */ } \\
& \text { Pol2Rec(r1, r2); } \\
& \text { /* Get true obliquity*/ } \\
& \text { Obliquity(J2000,TDB,1,\&TrueEps,\&TrueEpsDot); } \\
& \text { / Transform */ } \\
& \text { Eq2Ecl(r2, 0, TrueEps, r2); } \\
& \text { /* Change to polar variables */ } \\
& \operatorname{Rec} 2 \mathrm{Pol}(\mathrm{r} 2, \mathrm{r} 2) \text {; } \\
& \text { Lambda }=\text { r2[0] * R2D; } \\
& \text { Beta }=r 2[1] * \text { R2D; }
\end{aligned}
$$

First the $R A, \operatorname{Dec}$ values are changed in units of radians then each of them is entered in array $r 1$. Then the polar coordinates $r 1$ are changed to rectangular coordinates and then accommodated in $r 2$ with the Pol2Rec (polar to rectangular) function. Before the transformation from equatorial coordinates to ecliptic, we need one more variable, namely true obliquity (TrueEps). So it is called the Obliquity function. After the $r 2$ and TrueEps values are obtained then the transformation process is performed with the Eq2Ecl (equatorial to ecliptic) function in the rectangular coordinate format. To change it in polar coordinates, we call the Rec2Pol (rectangular to polar) function. Finally, lambda (ecliptic longitude) is the $0^{\text {th }}$ index of $r 2$ and beta (ecliptic latitude) is the $1^{\text {st }}$ index of $r 2$.

The next process is the calculation process to obtain the value of the semi diameter of the Sun or Moon in minutes. The value of the constant s and the formula of semi diameter and horizontal parallax the writer took from Jean Meeus's book, Astronomical Algorithm²5.

$$
\begin{gathered}
\text { SemiDiameter }=\frac{\frac{s}{r}}{60} \\
\sin \pi=\frac{6378,14}{\mathrm{r}} ; \pi=\text { Horizontal Parallax }
\end{gathered}
$$

$r=$ the distance of the Sun/Moon to Earth

The formula is written in the source code as follows.

$$
\text { if }(\text { Targ }==10)\left\{r=r^{*} \text { AU2KM; } s=358473400 ;\right\} \text { else }
$$

\footnotetext{
${ }^{25}$ For the semi-diameter formula, see: Meeus, Astronomical Algorithms, 359-361. Horizontal parallax formula, see: Meeus, 307.
} 


$$
\begin{gathered}
\text { if }(\operatorname{Targ}==11)\{r=r ; s=959.63 ;\} \\
\text { SemiDiameter }=(\mathrm{s} / \mathrm{r}) / 60 ; \\
\text { HorizontalMoonParallax=asin(6378.14/r*R2D; }
\end{gathered}
$$

As for the Equation of Time formula the authors quote from the Rinto Anugraha ${ }^{26}$ algorithm as follows:

$$
\begin{aligned}
& \mathrm{u}=(\mathrm{TDB}-2451545) / 36525 \text {; } \\
& 10=\text { amodulo }((280.46607+36000.7698 * \mathrm{u}), 360) * \mathrm{D} 2 \mathrm{R} \text {; } \\
& \text { EquationOfTime }=(-1 *(1789+237 * u) * \sin (10) \\
& -(7146-62 * \mathrm{u}) * \cos (10) \\
& +\left(9934-14^{*} \mathrm{u}\right) * \sin (2 * 10) \\
& -(29+5 * \mathrm{u}) * \cos (2 * 10) \\
& +(74+10 * \mathrm{u}) * \sin (3 * 10) \\
& +(320-4 * \mathrm{u}) * \cos (3 * 10) \\
& -212 * \sin (4 * 10)) / 1000 \text {; }
\end{aligned}
$$

\section{Solar Eclipse Calculation Algorithm Based on JPL Data NASA}

From the illustration in Figure 1 (middle) it can be mathematically modeled that the peak of a total solar eclipse occurs when the ecliptic longitude of the Sun and Moon and the ecliptic latitude of the Sun and Moon have the same value. In other words, the peak of a total or annular solar eclipse will occur when the SunMoon ecliptic longitude difference is zero and the Sun-Moon ecliptic latitude is also zero. At that time the angle formed between the Sun and the Moon viewed from Earth (the elongation angle) reaches the smallest value. So by looking for the smallest elongation angle value from the beginning to the end of the solar eclipse time, it can be seen when the total or annular peak solar eclipse occurs.

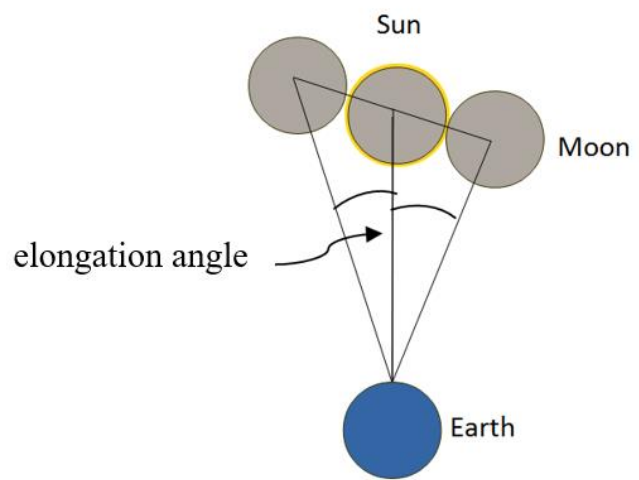

Figure 1. Illustration of changes in elongation angle at first contact, middle eclipse and last contact at a total or annular solar eclipse.

${ }^{26}$ Anugraha, Mekanika Benda Langit, 78-79. 


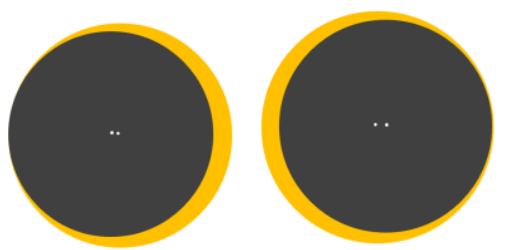

Figure 2. Illustration of the beginning (left) and the end (right) of a total or annular eclipse.

While the beginning of a partial eclipse (contact 1 ) and the beginning of a partial eclipse (contact 4, last contact) occur when the absolute value of the difference between the ecliptic longitude of the Sun and Moon is equal to 31' $31 " .52$ (see Figure 1 right and left). is the sum of the average values of the Sun's semi-diameter (15' 59".63) and the average semi-diameter of the Moon (15' $32 " .58)^{27}$, then to predict the beginning of the total eclipse (contact 2 ) and end total eclipse (contact 3) can be determined by comparing the ecliptic longitude difference of the Sun and Moon with the value $0^{\circ} 00^{\prime} 27^{\prime \prime} .05=0.007513889^{\circ}=$ 27.05 arc seconds. This value is the result of the difference between the average value of semi- the diameter of the Sun and the average semi-diameter of the Moon, the sum and the difference between the semi-diameter of the Sun and the Moon can also be determined on the fly with the Sephem program (Simple Ephemeris Program) so that the realtime value matches the semi-diameter values of the Sun and Moon when the process of accounting Sun eclipse.

Furthermore, by tracking the difference in ecliptic longitude of the Sun and Moon that meet the value before the peak of the eclipse will be obtained when the first contact occurs. The same thing is done to find the time of the last contact, the difference is the tracking process is done after the peak of the eclipse. The following snippet of the tracking process command in C language is implemented in the sephem program above.

1. if $($ counter $==0)\{$ Elo $=$ ellongation; Elo_t $=\mathrm{TDB} ;\}$

2. if(Elo $>$ ellongation $)\{$ Elo $=$ ellongation; Elo_t $=$ TDB; $\}$ else $\{$ Elo $=$ Elo; Elo_t $=$ Elo_t; $\}$

3. if(delta_Longitude $<=$ sum_SD \&\& flag $==0)\{$ flag $=1$; C1_time $=$ TDB; $\}$

4. if(delta_Longitude $>=$ sum_SD \& \& flag $==1 \& \&$ flag $2==0)\{$ flag $2=1$;

5. C4_time $=$ TDB; $\}$

27 The semi-diameter values of the Moon are 14' 41" to $16^{\prime} 45^{\prime \prime}$ and the semi-diameters of the Sun are 15' 46" and 16' 18". Office H.M. Nautical Almanac, Explanatory Supplement to The Astronomical Ephemeris and The American Ephemeris and Nautical Almanac (London: Her Majesty's Stationery Office, 1961), 215. 
6. if(delta_Longitude $=0.007513889 \& \&$ flag_C2 $==0) \quad\{$ flag_C2 $=1$; C2_time $=$ TDB;

7. if(delta_Longitude $=0.007513889 \& \&$ flag_C2 $==1 \& \&$ flag_C3==0) $\{$ flag_C3 $=1 ;$ C3_time $=$ TDB; $\}$

In order, the source code will look for the smallest elongation value and the time it occurred to determine when the eclipse peak (lines 1 to 11). In the next tracking process the first contact time is sought, when the absolute value of the ecliptic longitude (delta_Longitude) is smaller or equal to the number of semidiameters of the Sun and Moon (lines 13 to 15). Likewise, the last contact time was found when the absolute value of the ecliptic longitude (delta_Longitude) was greater or equal to the number of semi-diameters of the Sun and Moon (lines 17 to 20). In the source code is also carried out the tracking process to predict contact time 2 and contact 4 (lines 23 to 30). If the ecliptic longitude difference of the Sun and Moon meets certain predetermined values and this occurs before the peak of the gerhanana, then the time is determined as the start of contact 2 (lines 23-25). However, if the ecliptic longitude difference of the Sun and Moon is found after the peak of the eclipse then that is an early indication of contact 3 (lines 28-30).

From the source code it can be seen that the ephemeris data needed for the calculation of the total eclipse of the Sun or ring is the elongation angle, the difference in longitude of the Sun and Moon and the number of semi-diameters of the Sun and Moon and the difference in the semi-diameter of the Sun and Moon.

The elongation angle can be calculated with the following formula from Jean Meeus ${ }^{28:}$

$$
\begin{array}{cl}
\cos E=\cos \left(R A_{\text {moon }}-R A_{\text {sun }}\right) * \cos \left(D E C_{\text {sun }}\right) * \cos \left(D E C_{\text {moon }}\right)+\sin \left(D E C_{\text {sun }}\right) \\
\text { Where: }
\end{array} \quad \begin{aligned}
& \text { E } \\
& \text { RA_moon }\left(D E C_{\text {moon }}\right)
\end{aligned}
$$

To obtain the elongation angle values, 4 (four) Sun and Moon ephemeris data are needed in equatorial coordinates, namely the right askensio of the Sun and Moon (RA) and the declination of the Sun and Moon (DEC). The four data

28 Meeus, Astronomical Algorithms, 315. 
can be obtained using an algorithm written by Paul J. Heafner ${ }^{29}$ based on the NASA JPL ephemeris data DE200 and DE405 ${ }^{30}$ series below:

1. Reduce(TDB, Targ, Place, StarData, p3);

2. $r=\operatorname{sqrt}\left(\mathrm{p} 3[0]^{*} \mathrm{p} 3[0]+\mathrm{p} 3[1]^{*} \mathrm{p} 3[1]+\mathrm{p} 3[2]^{*} \mathrm{p} 3[2]\right)$;

3. RA_hours $=\operatorname{atan} 2(\mathrm{p} 3[1], \mathrm{p} 3[0]) * \mathrm{R} 2 \mathrm{H}$;

4. if (RA_hours $<0.0$ ) $\{$ RA_hours $+=24.0$;

5. DEC_deg $=\operatorname{asin}(\mathrm{p} 3[2] / \mathrm{r}) * \mathrm{R} 2 \mathrm{D}$;

After the $R A, \operatorname{Dec}$ and $r$ values are obtained, these values are used as parameters for the transformation to ecliptic coordinates with the following source code ${ }^{31}$.

1. $\mathrm{r} 1[0]=\mathrm{RA}$-hours $* \mathrm{H} 2 \mathrm{R}$;

2. $\mathrm{r} 1[1]=\mathrm{DEC}_{-}$deg $* \mathrm{D} 2 \mathrm{R}$;

3. $\mathrm{r} 1[2]=1.0$;

4. $\mathrm{r} 1[3]=0.0$;

5. $\mathrm{r} 1[4]=0.0$

6. $\mathrm{r} 1[5]=0.0$

7. Pol2Rec(r1, r2);

8. Obliquity(J2000,TDB,1,\&TrueEps,\&TrueEpsDot);

9. $\operatorname{Eq} 2 \operatorname{Ecl}(\mathrm{r} 2,0$, TrueEps, r2);

10. $\operatorname{Rec} 2 \mathrm{Pol}(\mathrm{r} 2, \mathrm{r} 2)$;

11. Lambda $=\mathrm{r} 2[0] * \mathrm{R} 2 \mathrm{D}$;

12. Beta $=r 2[1] * R 2 D ;$

The next process is the calculation process to obtain the value of the semi diameter of the Sun or Moon in minutes. The value of the constant $s$ and the semi-diameter formula the writer took from Jean Meeus's book, Astronomical Algorithms ${ }^{32}$.

$$
\begin{aligned}
\text { SemiDiameter }= & \frac{\frac{\mathrm{s}}{\mathrm{r}}}{60} \\
& =\text { Distance of the Moon to Earth }(\mathrm{km}) \\
\text { r_Moon } & =\text { Distance between Sun and Earth (Astronomical } \\
\text { r_Sun } & \quad \text { Units, AU) } \\
\text { s_Moon } & =358,473.400 \\
\text { s_Sun } & =959.63
\end{aligned}
$$

\footnotetext{
${ }^{29}$ Heafner, Fundamental Ephemeris Computations for Use with JPL Data, 101-103.

30 This data series can be downloaded on an FTP server that has been provided by NASA's JPL at $\mathrm{ftp}: / /$ ssd.jpl.nasa.gov/pub/eph/planets/ascii/ which must then be converted into a binary file first. In detail the process see: Heafner, 126-137.

31 Heafner, 56-60.

32 Meeus, Astronomical Algorithms, 359-361.
} 
So the algorithm offered in this paper for determining the peak time of an eclipse, the beginning and end of an eclipse both partial and total eclipses or annular eclipse begins with converting DE200 and DE405 data files into binary files. The binary file is then processed to obtain $R A$, Dec and $r$ values for the SunMoon. With RA and Dec values, elongation angle values and lambda and beta values can be obtained. While the value of $r$ can be determined by the semidiameter value of the Sun-Moon.

After obtaining the elongation angle value, longitude (lambda) of the Sun Moon and semi-diameter of the Sun - Moon, then the absolute value of the SunMoon difference is calculated and the number and difference of the semidiamter difference of the Sun - Moon as parameters for determining contact 1 , contact 2 , contact 3 and contact 4 in a total solar eclipse or ring as previously described. So finally the prediction of several important contacts in the total solar eclipse or the ring is ready to be used as a tool to compare the accuracy of the database used (DE200 and DE405) in the process of calculating the prediction.

\section{Comparison of DE200 and DE405 Series Accuracy}

Before comparing the solar eclipse computation results from the sephem program with the observational results, the following is described the 'Langit Selatan' observation data which was also reported by LAPAN for the total solar eclipse that occurred on March 9, 2016 with the location at SMKN 1 Maba Halmahera with coordinates $0.691482 \mathrm{~N} 128.219721 \mathrm{E}$ and the height of the place 114 meters $^{33}$.

In observing the March 9, 2016 solar eclipse in Maba there were activities carried out by two teams, namely the LAPAN and NASA teams conducted at the City Hall - Jiko Mobon Square, as well as the 'Langit Selatan ' team that made observations from SMK 1 Maba on Jl. Poros Soagimalaha Maba Soagimalaha Village Maba City Subdistrict East Halmahera Regency Maluku Province.

One consideration for choosing Halmahera as a location for observation is the height of the Sun during eclipse hours and weather patterns for the month. Its location overlooking the Pacific Ocean is one of the reasons for the selection of this place, because the potential for monitoring is more leverage because the

33 The coordinates and height of the observation site are tracked from the www.gpscoordinates.net web site that uses the API (Application Programming Interface) from Google Maps. 
estimated totality of the longest eclipse and weather conditions are generally brighter than other places ${ }^{34}$.

The eclipse process starts from 08.37 to 11:23 East Indonesian Time (WIT), while GMT occurs for 3 minutes from 09.52 to 09.55 WIT. However, even though it was predicted to be sunny, the weather in Maba changed with the rain. This causes direct monitoring of GMT in Maba to be not optimal but important contacts can be recorded by the 'Langit Selatan ' team ${ }^{35}$.

The official website of 'Langit Selatan ' reports in detail the results of these observations. The contacts reported are as follows ${ }^{36}$ :

1. Contact 1 (beginning of partial eclipse) : 08:37:00.1 WIT $-9=23: 37: 00.1$ UT

2. Contact 2 (beginning of total eclipse) : 09:52:58.5 WIT $-9=00: 52: 58.5$ UT

3. Great Eclipse (Middle Eclipse) : 09:54:38.1 WIT $-9=00: 54: 38.1$ UT

4. Contact 3 (the end of total eclipse) : 09:56:18.3 WIT $-9=00: 56: 18.3$ UT

5. Contact 4 (the end of partial eclipse) : 11:23:05.4 WIT $-9=02: 23: 05.4$ UT

The results of the comparison between observations of 'Langit Selatan' and prediction results based on the DE200 and DE405 series data can be seen in the following tables:

Table 1. Comparison of Langit Selatan Observations with the results of the sephem program at 1 second intervals.

\begin{tabular}{|c|c|c|c|c|c|}
\hline No & Contact & $\begin{array}{l}\text { Langit } \\
\text { Selatan }\end{array}$ & \multicolumn{2}{|c|}{ DE Series } & Difference \\
\hline \multirow{2}{*}{1} & \multirow{2}{*}{$1^{\text {st }}$} & \multirow{2}{*}{$23: 37: 00.1$} & 200 & $23: 38: 32.15$ & 0:01:32.05 \\
\hline & & & 405 & 23:38:33.15 & $0: 01: 33.05$ \\
\hline \multirow{2}{*}{2} & \multirow{2}{*}{$2^{\text {nd }}$} & \multirow{2}{*}{$0: 52: 58.5$} & 200 & $0: 54: 32.50$ & $0: 01: 34.00$ \\
\hline & & & 405 & $0: 54: 33.50$ & $0: 01: 35.00$ \\
\hline \multirow{2}{*}{3} & \multirow{2}{*}{$\begin{array}{l}\text { Great } \\
\text { Eclipse }\end{array}$} & \multirow{2}{*}{ 0:54:38.1 } & 200 & $0: 56: 00.58$ & $0: 01: 22.48$ \\
\hline & & & 405 & $0: 56: 01.58$ & $0: 01: 23.48$ \\
\hline \multirow{2}{*}{4} & \multirow{2}{*}{$3^{\text {rd }}$} & \multirow{2}{*}{$0: 56: 18.3$} & 200 & $0: 58: 21.30$ & $0: 02: 03.00$ \\
\hline & & & 405 & 0:58:23.30 & $0: 02: 05.00$ \\
\hline \multirow{2}{*}{5} & \multirow{2}{*}{$4^{\text {th }}$} & \multirow{2}{*}{$2: 23: 05.4$} & 200 & $2: 25: 33.63$ & $0: 02: 28.23$ \\
\hline & & & 405 & $2: 25: 34.63$ & $0: 02: 29.23$ \\
\hline
\end{tabular}

Table 1 shows that the DE200 series had a better difference than the DE40 5 series in all contacts tested. The difference between the two is $1.00-2.00$ seconds.

\footnotetext{
34 Lembaga Penerbangan dan Antariksa Nasional, 'The Elipse Gerhana Matahari Total, Catatam Peristiwa 9 Maret2016', 110.

35 Lembaga Penerbangan dan Antariksa Nasional, 110.

36 Avivah Yamami, ‘GMT 2016 Dari Maba Dan Buli', n.d.
} 
Table 2. Comparison of Langit Selatan Observations with the results of the sephem program at 0.1 second intervals

\begin{tabular}{|c|c|c|c|c|c|}
\hline No & Contact & $\begin{array}{l}\text { Langit } \\
\text { Selatan }\end{array}$ & \multicolumn{2}{|c|}{ DE Series } & Difference \\
\hline \multirow{2}{*}{1} & \multirow{2}{*}{$1^{\text {st }}$} & \multirow{2}{*}{$23: 37: 00.1$} & 200 & $23: 38: 32.16$ & 0:01:32.06 \\
\hline & & & 405 & $23: 38: 32.56$ & $0: 01: 32.46$ \\
\hline \multirow{2}{*}{2} & \multirow{2}{*}{$2^{\text {nd }}$} & \multirow{2}{*}{$0: 52: 58.5$} & 200 & $0: 54: 32.62$ & 0:01:34.12 \\
\hline & & & 405 & $0: 54: 33.68$ & $0: 01: 35.18$ \\
\hline \multirow{2}{*}{3} & \multirow{2}{*}{$\begin{array}{l}\text { Great } \\
\text { Eclipse }\end{array}$} & \multirow{2}{*}{$0: 54: 38.1$} & 200 & 0:56:00.80 & 0:01:22.70 \\
\hline & & & 405 & 0:56:01.30 & 0:01:23.20 \\
\hline \multirow{2}{*}{4} & \multirow{2}{*}{$3^{\text {rd }}$} & \multirow{2}{*}{$0: 56: 18.3$} & 200 & $0: 58: 20.85$ & $0: 02: 02.55$ \\
\hline & & & 405 & $0: 58: 23.45$ & 0:02:05.15 \\
\hline \multirow{2}{*}{5} & \multirow{2}{*}{$4^{\text {th }}$} & \multirow{2}{*}{$2: 23: 05.4$} & 200 & $2: 25: 33.23$ & $0: 02: 27.83$ \\
\hline & & & 405 & $2: 25: 33.73$ & $0: 02: 28.33$ \\
\hline
\end{tabular}

Meanwhile, when the ephemeris data interval was reduced to 0.1 seconds (Table 2) the DE200 series still had a good difference compared to DE405 series in all contacts tested. The difference between the two is getting closer, that is $0.400-2.600$ seconds.

Table 3. Comparison of Langit Selatan Observations with the results of the sephem program at 0.01 second intervals

\begin{tabular}{|c|c|c|c|c|c|}
\hline No & Contact & $\begin{array}{l}\text { Langit } \\
\text { Selatan }\end{array}$ & \multicolumn{2}{|c|}{ DE Series } & Difference \\
\hline \multirow{2}{*}{1} & \multirow{2}{*}{$1^{\text {st }}$} & \multirow{2}{*}{$23: 37: 00.1$} & 200 & $23: 38: 32.12$ & 0:01:32.02 \\
\hline & & & 405 & $23: 38: 32.51$ & $0: 01: 32.41$ \\
\hline \multirow{2}{*}{2} & \multirow{2}{*}{$2^{\text {nd }}$} & \multirow{2}{*}{$0: 52: 58.5$} & 200 & $0: 54: 32.60$ & $0: 01: 34.10$ \\
\hline & & & 405 & $0: 54: 33.62$ & $0: 01: 35.12$ \\
\hline \multirow{2}{*}{3} & \multirow{2}{*}{$\begin{array}{l}\text { Great } \\
\text { Eclipse }\end{array}$} & \multirow{2}{*}{$0: 54: 38.1$} & 200 & $0: 56: 00.81$ & $0: 01: 22.71$ \\
\hline & & & 405 & $0: 56: 01.27$ & $0: 01: 23.17$ \\
\hline \multirow{2}{*}{4} & \multirow{2}{*}{$3^{\text {rd }}$} & \multirow{2}{*}{$0: 56: 18.3$} & 200 & $0: 58: 20.80$ & $0: 02: 02.50$ \\
\hline & & & 405 & $0: 58: 23.40$ & $0: 02: 05.10$ \\
\hline \multirow{2}{*}{5} & \multirow{2}{*}{$4^{\text {th }}$} & \multirow{2}{*}{$2: 23: 05.4$} & 200 & $2: 25: 33.22$ & $0: 02: 27.82$ \\
\hline & & & 405 & $2: 25: 33.73$ & $0: 02: 28.33$ \\
\hline
\end{tabular}

Subsequent experiments with 0.01 second intervals (Table 3) showed that the DE200 series still consistently had a better difference than the DE405 series in all contacts tested. The difference between the two is getting closer namely 0.3907 - 0.4608 seconds at the first contact and the middle of the eclipse, as well as at the second contact that is 1.020 seconds. But on the last contact the difference between the two enlarged to 0.510 seconds and the difference in the second contact remained stable at a difference of 2.600 seconds. 
Table 4. Comparison of Langit Selatan Observations with the results of the sephem program at 0.001 second intervals

\begin{tabular}{|c|c|c|c|c|c|}
\hline No & Contact & $\begin{array}{l}\text { Langit } \\
\text { Selatan }\end{array}$ & \multicolumn{2}{|c|}{ DE Series } & Difference \\
\hline \multirow{2}{*}{1} & \multirow{2}{*}{$1^{\text {st }}$} & \multirow{2}{*}{$23: 37: 00.1$} & 200 & 23:38:32.12 & 0:01:32.02 \\
\hline & & & 405 & $23: 38: 32.51$ & $0: 01: 32.41$ \\
\hline \multirow{2}{*}{2} & \multirow{2}{*}{$2^{\text {nd }}$} & \multirow{2}{*}{$0: 52: 58.5$} & 200 & $0: 54: 32.09$ & $0: 01: 33.59$ \\
\hline & & & 405 & $0: 54: 33.60$ & $0: 01: 35.10$ \\
\hline \multirow{2}{*}{3} & \multirow{2}{*}{$\begin{array}{l}\text { Great } \\
\text { Eclipse }\end{array}$} & \multirow{2}{*}{$0: 54: 38.1$} & 200 & 0:56:00.81 & 0:01:22.71 \\
\hline & & & 405 & $0: 56: 01.28$ & 0:01:23.18 \\
\hline \multirow{2}{*}{4} & \multirow{2}{*}{$3^{\text {rd }}$} & \multirow{2}{*}{$0: 56: 18.3$} & 200 & $0: 58: 20.88$ & $0: 02: 02.58$ \\
\hline & & & 405 & $0: 58: 23.32$ & 0:02:05.02 \\
\hline \multirow{2}{*}{5} & \multirow{2}{*}{$4^{\text {th }}$} & \multirow{2}{*}{$2: 23: 05.4$} & 200 & $2: 25: 33.22$ & $0: 02: 27.82$ \\
\hline & & & 405 & $2: 25: 34.72$ & $0: 02: 28.32$ \\
\hline
\end{tabular}

Table 4 shows the DE200 series still has a better difference than the DE405 series in all contacts tested. The difference between the two is stable at the first contact ( 0.390 seconds) and getting closer to the 3rd contact ( 2.440 seconds) and the 4th ( 0.500 seconds). While the difference between the eclipses in the middle of the difference between the two enlarged slightly from 0.460 seconds to 0.470 seconds, so also in the second contact from 1,020 seconds to 1.510 seconds compared to when the 0.01 second interval was used (Table 3 ).

Table 5. Comparison of Langit Selatan Observations with the results of the sephem program at 0.0001 second intervals

\begin{tabular}{|c|c|c|c|c|c|}
\hline No & Contact & $\begin{array}{l}\text { Langit } \\
\text { Selatan }\end{array}$ & \multicolumn{2}{|c|}{ DE Series } & Difference \\
\hline \multirow{2}{*}{1} & \multirow{2}{*}{$1^{\text {st }}$} & \multirow{2}{*}{$23: 37: 00.1$} & 200 & $23: 38: 32.12$ & $0: 01: 32.02$ \\
\hline & & & 405 & $23: 38: 32.51$ & $0: 01: 32.41$ \\
\hline \multirow{2}{*}{2} & \multirow{2}{*}{$2^{\text {nd }}$} & \multirow{2}{*}{$0: 52: 58.5$} & 200 & $0: 54: 32.02$ & 0:01:33.52 \\
\hline & & & 405 & $0: 54: 33.07$ & $0: 01: 34.57$ \\
\hline \multirow{2}{*}{3} & \multirow{2}{*}{$\begin{array}{l}\text { Great } \\
\text { Eclipse }\end{array}$} & \multirow{2}{*}{$0: 54: 38.1$} & 200 & $0: 56: 00.81$ & $0: 01: 22.71$ \\
\hline & & & 405 & $0: 56: 01.28$ & $0: 01: 23.18$ \\
\hline \multirow{2}{*}{4} & \multirow{2}{*}{$3^{\text {rd }}$} & \multirow{2}{*}{$0: 56: 18.3$} & 200 & $0: 58: 20.84$ & $0: 02: 02.54$ \\
\hline & & & 405 & 0:58:22.88 & 0:02:04.58 \\
\hline \multirow{2}{*}{5} & \multirow{2}{*}{$4^{\text {th }}$} & \multirow{2}{*}{$2: 23: 05.4$} & 200 & $2: 25: 33.21$ & 0:02:27.81 \\
\hline & & & 405 & $2: 25: 33.72$ & $0: 02: 28.32$ \\
\hline
\end{tabular}

In the last experiment when the interval was reduced to 0.0001 seconds (Table 5) the DE200 series still had a good difference compared to DE405 series in all contacts tested. The difference between the two remains for the first contact time and the middle of the eclipse. The closer for the second contact 
(1.510 to 1.050 seconds) and the third contact (2.440 to 2.040 seconds) and the enlarged for the last contact ( 0.500 to 0.510 seconds).

Table 6. Characteristics of changes in DE200 and DE405 series differences in some ephemeris data interval variations with the first contact reference

\begin{tabular}{c|c|c|c|c|c|c|c}
\hline \multirow{2}{*}{ No } & \multirow{2}{*}{ Contact } & \multirow{2}{*}{$\begin{array}{c}\text { DE } \\
\text { Series }\end{array}$} & \multicolumn{5}{|c}{ Ephemeris Data Interval (seconds) } \\
\cline { 4 - 8 } & & \multirow{3}{*}{1} & 1 & 0.1 & 0.01 & 0.001 & 0.0001 \\
\hline \multirow{2nnyyyyy}{*}{2} & & DE200 & $0: 01: 32.05$ & $0: 01: 32.06$ & $0: 01: 32.02$ & $0: 01: 32.02$ & $0: 01: 32.02$ \\
\cline { 4 - 8 } & & DE405 & $0: 01: 33.05$ & $0: 01: 32.46$ & $0: 01: 32.41$ & $0: 01: 32.41$ & $0: 01: 32.41$ \\
\hline
\end{tabular}

Table 7. Characteristics of changes in DE200 and DE405 series differences in various ephemeris data intervals with the 2 nd contact reference

\begin{tabular}{c|c|c|c|c|c|c|c}
\hline \multirow{2}{*}{ No } & \multirow{2}{*}{ Contact } & \multirow{2}{*}{$\begin{array}{c}\text { DE } \\
\text { Series }\end{array}$} & \multicolumn{5}{|c}{ Ephemeris Data Interval (seconds) } \\
\cline { 3 - 8 } & & 1 & 0.1 & 0.01 & 0.001 & 0.0001 \\
\hline \multirow{2}{*}{1} & \multirow{2}{*}{$2^{\text {nd }}$} & DE200 & $0: 01: 34.00$ & $0: 01: 34.12$ & $0: 01: 34.10$ & $0: 01: 33.59$ & $0: 01: 33.52$ \\
\cline { 3 - 8 } & & DE405 & $0: 01: 35.00$ & $0: 01: 35.18$ & $0: 01: 35.12$ & $0: 01: 35.10$ & $0: 01: 34.57$ \\
\hline
\end{tabular}

Table 8. Characteristics of changes in the difference between the series DE200 and

DE405 in several variations of the ephemeris data interval with reference to the great eclipse.

\begin{tabular}{c|c|c|c|c|c|c|c}
\hline \multirow{2}{*}{ No } & \multirow{2}{*}{ Contact } & DE & \multicolumn{5}{|c}{ Ephemeris Data Interval (seconds) } \\
\cline { 4 - 8 } & & Series & 1 & 0.1 & 0.01 & 0.001 & 0.0001 \\
\hline \multirow{2}{*}{1} & \multirow{2}{*}{ Great Eclipse } & DE200 & $0: 01: 22.48$ & $0: 01: 22.70$ & $0: 01: 22.71$ & $0: 01: 22.71$ & $0: 01: 22.71$ \\
\cline { 3 - 8 } & & DE405 & $0: 01: 23.48$ & $0: 01: 23.20$ & $0: 01: 23.17$ & $0: 01: 23.18$ & $0: 01: 23.18$ \\
\hline
\end{tabular}

Table 9. Characteristics of changes in the difference in the DE200 and DE405 series in several variations of the ephemeris data interval with the 3rd contact reference

\begin{tabular}{c|c|c|c|c|c|c|c}
\hline \multirow{2}{*}{ No } & \multirow{2}{*}{ Contact } & \multirow{2}{*}{\begin{tabular}{c} 
DE \\
\cline { 3 - 7 }
\end{tabular}} & Series & \multicolumn{5}{|c}{ Ephemeris Data Interval (seconds) } \\
\cline { 4 - 8 } & \multirow{2}{*}{$3^{\text {rd }}$} & DE200 & $0: 02: 03.00$ & $0: 02: 02.55$ & $0: 02: 02.50$ & $0: 02: 02.58$ & $0: 02: 02.54$ \\
\cline { 3 - 8 } 2 & & DE405 & $0: 02: 05.00$ & $0: 02: 05.15$ & $0: 02: 05.10$ & $0: 02: 05.02$ & $0: 02: 04.58$ \\
\hline
\end{tabular}

Table 10. Characteristics of changes in DE200 and DE405 series differences in various ephemeris data intervals with the last contact reference (4th contact)

\begin{tabular}{c|c|c|c|c|c|c|c}
\hline \multirow{2}{*}{ No } & \multirow{2}{*}{ Contact } & \multirow{2}{*}{\begin{tabular}{c} 
DE \\
\cline { 3 - 7 }
\end{tabular}} & Series & \multicolumn{5}{|c}{ Ephemeris Data Interval (seconds) } \\
\cline { 4 - 8 } & \multirow{2}{*}{$4^{\text {th }}$} & DE200 & $0: 02: 28.23$ & $0: 02: 27.83$ & $0: 02: 27.82$ & $0: 02: 27.82$ & $0: 02: 27.81$ \\
\cline { 3 - 8 } 2 & & DE405 & $0: 02: 29.23$ & $0: 02: 28.33$ & $0: 02: 28.33$ & $0: 02: 28.32$ & $0: 02: 28.32$ \\
\hline
\end{tabular}


M Basthomi

Furthermore, if the characteristics of the change in the difference between the DE200 and DE405 series are considered, for the first contact reference (Table 6) and the second (Table 7) the difference between the two continues to decrease at the interval that was tried in this study. While for the middle of the eclipse (Table 8) the difference between the two waned initially but the difference enlarged in the last two intervals ( 0.001 and 0.0001 seconds). Whereas for the 3rd contact time (Table 9) the difference between the two waned initially but the difference widened at the last three intervals $[0.01,0.001$ and 0.0001 seconds). On the other hand, when the reference is the last contact time (Table 10), the difference between the two is very volatile. Initially the difference is large enough then shrink, enlarge and shrink back.

Better accuracy of DE200 compared to DE405 as shown in the comparison data above, it is not only important to use in the selection of better and more careful data in determining the last times of the solar eclipse prayer, but the determination of the middle eclipse time also has a close correlation choosing a more rigorous algorithm in determining the time of conjunction as a reference for the beginning of the Islamic month.

Regarding the recitation of the solar eclipse prayer, the Koran, 41: 37 hints as follows:

And some of the signs of His greatness are night, day, Sun and Moon. Do not prostrate to the Sun and not (also) to the Moon, but prostrate to God who created it, if you only worship Him.

According to Muhammad al-Sharbinīi ${ }^{37}$ the verse is related to eclipse prayer. According to him the prohibition of worshiping the Sun and Moon in the verse and the command to worship God who created them was when an eclipse occurred. This he based on the hadith of the Prophet Muhammad: 38

Surely there was a solar eclipse in the time of the Prophet Muhammad. Then he stood up then bowled and then stood up again and bowled again then stood again then bowled twice in three rak'ahs and four prostrations. When he finished praying, the Sun had recovered. When bowing he read "Allāh akbar" then bow. When he raised his head (i'tidāl) he said "sami'a Allāh li man hamidah". Then he stood up and praised Allah and said: "Surely the Sun and the Moon did not experience an eclipse because of death or life, but both are part of a sign of the greatness of God to give fear

\footnotetext{
37 Muhammad Al-Sharbinī, Al-Iqnā' Fì Hill Alfāz Abī Shujā', I, vol. I, n.d., 163.

38 Muslim bin Al-Hajjāj, Sạhị̣ Muslim, 397-398.
} 
to His servants. So, if you see an eclipse then dhikr on Him until both of them recover from eclipse".

The Hadith also becomes one of the grounds that the law of eclipse prayer is sunnah mu'akkada ${ }^{39}$. Even though the hadith has the word command, it does not show obligation because there are other indications that indicate otherwise ${ }^{40}$. The indications are that the Prophet always perpetuates eclipse prayers when an eclipse occurs but, on another occasion, the Prophet also said that prayers in addition to the five times are tatawwu' prayer (sunnah). As the following words of the Prophet. ${ }^{41}$

A man from the Najd had come up with his head up, his voice was loud but could not be understood what he was saying until he approached the Prophet. Suddenly he asked about Islam. The Prophet also said: (do) pray five times a day overnight. Then he asked: is there still another obligation (salat)? The Prophet said: 'No, unless you carry out the prayers of tațawwu' (sunnah)'

Related to the time of the solar eclipse prayer, in the hadith of the Muslim history the Prophet also hinted at the time of its implementation until the Sun recovered. So knowing when an eclipse starts and when it ends will be important because it relates to the legal requirements for prayer.

The scholars agree that one of the legal requirements for prayer is knowing when to enter the prayer time. Al-Malibary ${ }^{42}$ asserted that whoever performs the prayer without knowing the time, the prayer is invalid even if he performs it

\footnotetext{
${ }^{39}$ In this case Ibn Rushd stated that the scholars agreed that the law of the solar eclipse prayer was sunnah. The difference of the scholars is only in the technical implementation of the prayer. See: Muhammad bin Ahmad bin Muhammad bin Ahmad Ibn Rushd, Bidāyah Al-Mujtahid Wa Nihāyah AlMuqtașid, I (Surabaya: Dār Ihyāi' al-Kutub al-'Arabiyah, n.d.), 152; Muhammad Shața al-Dimyați also believes that based on the hadith of the Muslim history the law of the solar eclipse prayer is the sunnah muakkadah.See: Muḥammad Shața Al-Dimyațī, Huasshiyah I'ānah al-Ṭālibìn, I(Libanon: Dāral-Fikr, n.d.), 262.
}

40 This is in line with the principles of jurisprudence:

$$
\text { الأصل في الأمر للوجوب إلا ما دل الدليل على خلافه }
$$

See: Abdul Hamid Hakim, Mabādi' Awwaliyah (Jakarta: Sa'adiyah Putra, n.d.), 8; In this case Muhammad bin Ahmad al-Mahally added that the meaning of orders, especially those that use forms إفْعَلْ has many possible meanings among them are mandatory and sunnah. According to the majority of scholars the meaning of the command is obligatory. But when there is 'alaqah (other conditions that affect it), the meaning of the command can shift between the obligatory and the sunnah. See: Muhammad bin Ahmad Al-Mahallī, Hāshiyah Al-'Allāmah Al-Bannānīi I (Indonesia: Dār Ihyā' al-Kutub al-'Arabiyyah,n.d.), 372.

${ }^{41}$ Muḥammad bin Ismā'îl Al-Bukhārī, Matn Al-Bukhārī, I (Semarang: Toha Putera, n.d.), 17.

${ }^{42}$ Al-Dimyāțī, Ḥāshiyah I'ānah al-Ṭālibīn, 115; Zakariyā, Fath Al-Wahhāb, 48. 
on time. Because what becomes a valid guide for whether or not a worship is a belief in oneself carrying out worship (zann al-mukallaf) and the worship is actually carried out right at the time of worship referred to ( $m \bar{a}$ fi nafs al-amr). A similar opinion was also written by al-Bayjürīi3 ${ }^{3}$. He argues that people who will carry out eclipse prayers must be sure that an eclipse is happening. If he is doubtful he is not allowed to perform the eclipse prayer because in principle (ashal) the eclipse does not occur. As the rules of fiqh that read:

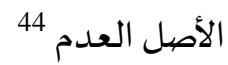

The origin of things is nothingness

Related to the time of the solar eclipse prayer, Ibn 'Alī Nawawīin added that the beginning of the solar eclipse prayer time began when there was a change in the shape of the Sun because it was covered by the disc of the Sun while the time of the solar eclipse prayer ended when the Sun had recovered as it was or the Sun had set even though it was still in an eclipse state.

Astronomically, the beginning of an eclipse as the beginning of an eclipse prayer time and the end of an eclipse as the end time of an eclipse prayer is called the first contact and the last contact. The time of the first and last contact can be predicted with a sephem program that utilizes the JPL ephemeris data from the NASA DE200 series which is proven to have good accuracy and very close reports of observations as described previously.

\section{Conclusion}

Based on the analysis of the computational experimental data conducted in this study presented in Tables 1 to Tables 10, it can be concluded that by using the algorithm proposed in this paper it is found that DE200 data has better accuracy than DE405, where the difference between the two is $0.5-0.6$ seconds at ephemeris data intervals $1-0.0001$ seconds. So this is one of the reasons why NASA is still using VSOP87/ELP2000 based on DE200 and at the same time also using DE405 as a database to release information about solar eclipses. Because

\footnotetext{
43 Ibrāhīm Al-Bayjūrī, Hāāshiyah Al-Shaykh Ibrāhīm Al-Bayjūrī, I (Libanon: Dār al-Fìkr, n.d.), 238.

${ }^{44}$ Abdul Hamid Hakim, Al-Sulam (Jakarta: as-Sa'diyah Putera, n.d.), 55.

45 Muhammad bin Amr bin 'Alī Nawawī, Nihāyah al-Zayn Fì Irshād Al-Mubtadi'īn (Libanon: Dār alFikr, n.d.), 110; Muḥammad Al-Sharbinī, al-Iqnā' fi Hill Alfāz Abī Shujā', I (n.d.), 163.
} 
the difference between the two is very close that is, on average, less than 1 second.[a]

\section{BIBLIOGRAPHY}

Aini, Fiki Nu'afi Qurrota. 'Studi Komparatif Sistem Perhitungan Gerhana Matahari Elements of Solar Eclipses Jean Meeus dan Textbook on Spherical Astronomy W.M. Smart'. Program Studi Ilmu Falak Fakultas Syariah dan Hukum UIN Walisongo Semarang, 2019.

Anugraha, Rinto. Mekanika Benda Langit. Yogyakarta: Lab. Material Physics and Instrumentation Department of Physics FMIPA UGM, 2012.

Azhari, Susiknan. Ensiklopedi Hisab Rukyat. Yogyakarta: Pustaka Pelajar, 2008.

Al-Bayjūrī, Ibrāhīm. Hāshiyah Al-Shaykh Ibrāhīm Al-Bayjūrī. I. Libanon: Dār al-Fikr, n.d.

Bretagnon, P. 'Theorie Du Mouvement de l'ensemble Des Planetes (VSOP82)'. Astronomy and Astrophysics 114 (1982): 278.

Bretagnon, P., and G. Francou. 'Planetary Theories in Rectangular and Spherical Variables: VSOP87 Solution'. Astronomy and Astrophysics 202 (1988): 309.

Al-Bukhārī, Muhammad bin Ismā'îl. Matn Al-Bukhārī. I. Semarang: Toha Putera, n.d.

Chapront-Touze, M., and J. Chapront. 'ELP 2000-85: A Semi-Analytical Lunar Ephemeris Adequate for Historical Times'. Astronomy and Astrophysics 190 (1988): 342.

Departemen Agama RI. Al-Qur'an dan Terjemahnya. Semarang: CV Al Waah, 2004.

Al-Dimyāțī, Muḥammad Shața. Ḥāshiyah I'ānah al-Ṭālibīn. I. Libanon: Dār al-Fikr, n.d.

Espenak, Fred. 'Solar Eclipse Predictions with JPL DE405', n.d.

Falih, Muhammad. 'Metode Hisab Gerhana Matahari Menurut Ali Mustofa dalam Kitab Al-Natijah Al-Mahșūnah'. Program Studi Ilmu Falak Fakultas Syariah dan Hukum UIN Walisongo, 2019.

Hakim, Abdul Hamid. Al-Sulam. Jakarta: as-Sa'diyah Putera, n.d. 
M Basthomi

——_. Mabādi' Awwaliyah. Jakarta: Sa'adiyah Putra, n.d.

Hamdani. Filsafat Ilmu. Bandung: Pustaka Setia, 2011.

Heafner, Paul J. Fundamental Ephemeris Computations for Use with JPL Data. Virginia: Willmann-Bell, Inc., 1999.

Ibn Rushd, Muhammad bin Ahmad bin Muhammad bin Ahmad. Bidāyah Al-Mujtahid Wa Nihāyah Al-Muqtașid. I. Surabaya: Dār Ihyā' al-Kutub al-'Arabiyah, n.d.

Lembaga Penerbangan dan Antariksa Nasional. 'The Elipse Gerhana Matahari Total, Catatam Peristiwa 9 Maret 2016', n.d.

Meeus, Jean. Astronomical Algorithms. Richmond: Willmann-Bell, Inc., 1991.

Al-Mahallī, Muhammad bin Ahmmad. Hāshiyah Al-'Allāmah Al-Bannānī. I. Indonesia: Dār Ihyā' al-Kutub al-'Arabiyyah, n.d.

Mukarromah, Siti Lailatul. 'Perhitungan Gerhana Matahari dengan Algoritma NASA'. Ulul Albab: Jurnal Studi dan Penelitian Hukum $\begin{array}{lllll}\text { Islam 2019): } & 2 \text { no. } & 2 & \end{array}$ https://doi.org/10.30659/jua.v2i2.3642.

Muslim bin Al-Hajjāj. Ṣaḥịh Muslim. I. Libanon: Dār al-Fikr, 1992.

NASA. 'About JPL Solar System Dynamics', n.d.

___. 'Annular Solar Eclipse of 2012 May 20', n.d.

___. 'Annular Solar Eclipse of 2021 Jun 10', n.d.

- - - 'Jet Propulsion Laboratory', n.d.

_-_. 'JPL Planetary and Lunar Ephemerides : Export Information', n.d.

___. 'Total Solar Eclipse of 2010 Jul 11', n.d.

_-_. 'Total Solar Eclipse of 2020 Dec 14', n.d.

Nawawī, Muhammad bin 'Amr bin 'Alī. Nihāyah Al-Zayn Fī Irshād AlMubtadi'īn. Libanon: Dār al-Fikr, n.d.

Office H.M. Nautical Almanac. Explanatory Supplement to The Astronomical Ephemeris and The American Ephemeris and Nautical Almanac. London: Her Majesty's Stationery Office, 1961.

Setyanto, Hendro. Membaca Langit. Jakarta: al-Ghuraba, 2008.

Al-Sharbinī, Muhammad. Al-Iqnā' Fī Hịll Alfāz Abī Shujā'. I. Vol. I, n.d.

Yamami, Avivah. 'GMT 2016 Dari Maba Dan Buli', n.d.

Zakariyā, Abī Yahyā. Fath Al-Wahhāb. I. Semarang: Usaha Keluarga, n.d. 